University of Nebraska - Lincoln

DigitalCommons@University of Nebraska - Lincoln

USDA Wildlife Services - Staff Publications

U.S. Department of Agriculture: Animal and Plant Health Inspection Service

2021

\title{
Impacts of a large invasive mammal on water quality in riparian ecosystems
}

Sara Bolds

Auburn University, szb0132@auburn.edu

B. Graeme Lockaby

Auburn University, lockabg@auburn.edu

Stephen S. Ditchkoff

Auburn University, ditchss@auburn.edu

Mark D. Smith

Auburn University, mds0007@aces.edu

Kurt C. Vercauteren

APHIS, kurt.c.vercauteren@usda.gov

Follow this and additional works at: https://digitalcommons.unl.edu/icwdm_usdanwrc

Part of the Natural Resources and Conservation Commons, Natural Resources Management and

Policy Commons, Other Environmental Sciences Commons, Other Veterinary Medicine Commons,

Population Biology Commons, Terrestrial and Aquatic Ecology Commons, Veterinary Infectious Diseases

Commons, Veterinary Microbiology and Immunobiology Commons, Veterinary Preventive Medicine,

Epidemiology, and Public Health Commons, and the Zoology Commons

Bolds, Sara; Lockaby, B. Graeme; Ditchkoff, Stephen S.; Smith, Mark D.; and Vercauteren, Kurt C., "Impacts of a large invasive mammal on water quality in riparian ecosystems" (2021). USDA Wildlife Services Staff Publications. 2433.

https://digitalcommons.unl.edu/icwdm_usdanwrc/2433

This Article is brought to you for free and open access by the U.S. Department of Agriculture: Animal and Plant Health Inspection Service at DigitalCommons@University of Nebraska - Lincoln. It has been accepted for inclusion in USDA Wildlife Services - Staff Publications by an authorized administrator of DigitalCommons@University of Nebraska - Lincoln. 
Wetlands and Aquatic Processes

\title{
Impacts of a large invasive mammal on water quality in riparian ecosystems
}

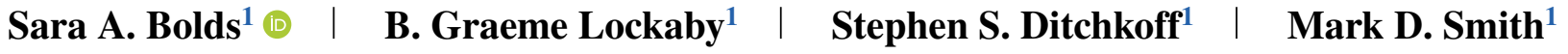 \\ Kurt C. VerCauteren ${ }^{2}$
}

${ }^{1}$ Auburn Univ., School of Forestry and Wildlife Sciences, 602 Duncan Drive, Auburn, AL 36849, USA

${ }^{2}$ National Wildlife Research Center, USDA/APHIS/Wildlife Services, Fort Collins, CO 80521, USA

\section{Correspondence}

Sara A. Bolds, Auburn Univ., School of Forestry and Wildlife Sciences, 602 Duncan Drive, Auburn, AL 36849, USA.

Email:szb0132@auburn.edu

Assigned to Associate Editor Tim Johnson

\begin{abstract}
Wild pigs (Sus scrofa) are a highly invasive species in many regions of the world and can act as ecosystem engineers in areas where they are established. In riparian ecosystems, wild pigs may affect water quality parameters and introduce fecal bacteria, although previous studies have reported conflicting results. We propose four conditions that we believe are needed for an accurate assessment of wild pig impacts on water quality and address each one in our study. Water samples were collected between May 2018 and June 2019 in riparian watersheds on a privately owned property in Alabama that was densely populated by wild pigs (treatment) and in watersheds at a nearby national forest without an established population. Samples were analyzed for concentrations of water quality parameters, such as anions and cations, dissolved oxygen, total suspended solids, N, dissolved organic C, and Escherichia coli and other fecal coliforms. An additional 38 samples were analyzed using quantitative polymerase chain reaction for swine fecal bacteroidetes. At treatment watersheds, specific conductivity and concentrations of organic $\mathrm{N}$ and $\mathrm{C}, \mathrm{SO}_{4}{ }^{2-}$, and $\mathrm{Ca}^{2+}$ were between 2 and 11 times that of reference watersheds. Escherichia coli values at treatment watersheds were 40 times reference watershed values. DNA from swine fecal bacteroidetes was detected in $70 \%$ of treatment samples and $0 \%$ of reference samples. Wild pigs are a threat to water quality in riparian areas, and our results indicate that it may be important to control populations upstream of major drinking water sources and recreational areas.
\end{abstract}

\section{1 | INTRODUCTION}

As global development continues to bring urban and rural landscapes closer together, watershed health and security are increasingly threatened by changes in land use and the resulting environmental conditions. Urban development,

Abbreviations: cfu, colony-forming unit; DO, dissolved oxygen; DOC, dissolved organic carbon; FC, fecal coliforms; MST, microbial source tracking; TN, total nitrogen; TSS, total suspended solids. agricultural activities, and degradation and invasion of natural landscapes all influence local watershed health and can affect the quantity and quality of water available (Baldwin \& Batzer, 2012). Riparian and wetland forest ecosystems play a vital role as the "kidneys" of a watershed because they filter pollutants and sediment from the aquatic system through biological, chemical, and physical means (Jolley et al., 2010). Removal of dissolved chemicals and sediment improves water quality, and nutrient uptake ensures adequate nutrient cycling through the terrestrial-aquatic interface. Riparian

(C) 2021 The Authors. Journal of Environmental Quality (C) 2021 American Society of Agronomy, Crop Science Society of America, and Soil Science Society of America 
areas provide important ecological services, such as habitat and resources for plant and animal communities and surface water storage. Additionally, riparian areas support commercial industries (e.g., agriculture and livestock production) and recreational hunting and fishing activities.

Improper sanitation management, stormwater runoff from urban and residential areas, poor land-use practices, and agricultural runoff are some potential causes of degraded water quality in local watersheds. However, the presence of livestock and wildlife in a watershed may reduce water quality as well. Livestock may contaminate stream water through direct contact or from runoff contaminated with feces and urine (Davies-Colley et al., 2004; Line et al., 2000), and subsequent use of contaminated water has been linked to disease outbreaks in humans (Ackers et al., 1998; Jay et al., 2007; Lindqvist et al., 2008). Wildlife species have also been documented as a source of waterborne fecal bacteria pollution. Escherichia coli and enterococci from gull (Larus sp.) feces has been detected at beaches in the Great Lakes in Illinois and Michigan (Fogarty et al., 2003), and E. coli from white-tailed deer (Odocoileus virginianus) and Canada geese (Branta canadensis) has been found in watersheds of the Finger Lakes in New York (Somarelli et al., 2007).

Direct impacts by wildlife on other water quality parameters are less documented, but indirect impacts of wildlife feeding or nesting behaviors can be substantial. For example, grazing by Canada geese can reduce the abundance of wetland vegetation, thereby limiting the ability of a watershed to filter and retain sediment and nutrients (Baldwin \& Pendleton, 2003). As ecosystem engineers, beavers (Castor canadensis) alter the vegetative structure, biogeochemistry, geomorphology, and hydrology of wetlands by felling trees and building dams (Johnston, 2012; National Research Council, 2002). For example, beaver impoundments can elevate the water table by controlling stormflow (Wigley \& Lancia, 1998), reduce water velocity and streambank erosion (Maret et al., 1987), increase $\mathrm{NH}_{4}{ }^{+}$concentrations in sediment (Naiman et al., 1994), and increase aquatic microbial activity (Songsteralpin \& Klotz, 1995).

Wild pigs (Sus scrofa) are quickly gaining a reputation as a threat to wetland and riparian ecosystems. Invasive to North America and many other parts of the world, wild pigs occur at high densities throughout much of the southeastern United States and frequently use wetlands and riparian forests for their habitat requirements (Lewis et al., 2019; Mayer et al., 2020). Wild pigs dig and overturn soil in search of food and create wallows for thermoregulation and ecto-parasite removal (Bracke, 2011; Gray et al., 2020; Howe \& Bratton, 1976). This rooting behavior can have serious consequences on the physical structure of ecosystems by causing increased erosion, destroying vegetative communities (Henry \& Conley, 1972; Ralph \& Maxwell, 1984; Wood \& Roark, 1980), and introducing pathogens, parasites, and invasive species

\section{Core Ideas}

- Wild pigs are a threat to water quality in riparian areas.

- Wild pigs introduced fecal material and bacteria to streams.

- Watersheds with wild pigs had elevated DOC and TN compared with reference watersheds.

- E. coli values in treatment watersheds were 40 times those of reference watersheds.

- We propose four guidelines to assess the impacts of wild pigs on water quality.

(Chalkowski et al., 2018; Cushman et al., 2004; Seward et al., 2004). As a result, wild pigs have significant potential to alter the functionality of wetland and riparian ecosystems, and their impacts are of great concern because riparian ecosystems provide essential ecological services and are sensitive to disturbance (King, Battaglia et al., 2012; National Research Council, 2002).

Few studies have examined the impacts of wild pig disturbance on water quality and fecal bacteria in riparian areas, and those that have either did not find significant impacts or their results conflicted with other literature (e.g., Beasley et al., 2018). These inconsistencies have generally been due to variability in experimental design, environmental conditions, land cover and use, density of wild pigs, and parameters selected for measurement. Doupé et al. (2010) conducted a study in northeastern Australia during the dry season with small ephemeral lagoons and concluded that the ability of wild pigs to access lagoons affected some water quality parameters. Lagoons with wild pigs had lower $\mathrm{pH}$, greater turbidity, and lower dissolved oxygen (DO) concentrations than lagoons that were not accessible by wild pigs, but nutrients and aquatic communities did not differ between treatments. Kaller and Kelso (2003) examined water quality in a single watershed in Louisiana and reported greater fecal coliforms (FC) and the presence of pathogenic bacteria at locations with evidence of wild pig activity. In contrast to Doupé et al. (2010), they did not observe differences in DO and stream habitat due to wild pig disturbance. Singer et al. (1984) observed greater $\mathrm{NO}_{3}{ }^{-}$ concentrations in stream water from a rooted hardwood stand in Great Smoky Mountains National Park in Tennessee compared with stream water from an unrooted stand but did not find a difference in suspended solids. Two studies conducted in tropical forests in Hawaii analyzed runoff from fenced and unfenced plots with wild pig activity, and neither found differences in concentration of suspended solids or fecal bacteria due to fencing treatment (Dunkell, Bruland, Evensen, \& Litton, 2011; Dunkell, Bruland, Evensen, \& 
Walker, 2011; Strauch et al., 2016). Brooks et al. (2020) compared runoff from a paddock containing wild pigs with a nearby stream, but runoff samples did not significantly differ from stream samples in concentrations of $\mathrm{NO}_{3}{ }^{-}$and $\mathrm{NO}_{2}{ }^{-}$, $\mathrm{NH}_{4}{ }^{+}$, fecal bacteria, or pathogenic bacteria. Wild pigs have been found to carry waterborne pathogens such as Giardia and Cryptosporidium (Atwill et al., 1997; Hampton, Spencer, Elliot, \& Thompson, 2006), but, to our knowledge, no study to date has been able to link waterborne pathogens in the environment to the presence of wild pigs.

The substantial variability in reported results, experimental designs, environmental conditions, and land cover and use of previous studies examining the impacts of wild pigs on water quality has created considerable confusion. As a result, our goal was to examine the impacts of wild pigs on water quality in headwater riparian systems using an experimental design that used the conditions we felt must be met for a thorough assessment of wild pig impacts on water quality. These conditions include: (a) Wild pigs must be present in and have access to the area being studied, (b) the pigs must be free to exhibit natural behavior, (c) the receiving body of water should represent natural flow, and (d) the water sampling technique must be sufficiently rigorous to detect subtle changes against a backdrop of high variability. Studies that use these guidelines would have greater capability of assessing the effects of wild pigs on water quality and can subsequently be used for guiding wild pig management and control initiatives to safeguard water quality in local watersheds. Our specific research objectives were (a) to identify multiple small watersheds with free-roaming wild pigs to observe changes in water quality parameters in a natural setting with minimal background variability and human activity, (b) to determine impacts on water quality by measuring nutrient concentrations and physiochemical parameters in forested headwater stream systems, and (c) to determine impacts on fecal bacteria concentrations by analyzing stream water for the presence of swine fecal bacteria and quantifying $E$. coli and fecal coliform concentrations.

\section{2 | MATERIALS AND METHODS}

\section{1 | Study area}

We worked at a privately owned property with a high density of wild pigs (i.e., treatment area) and on the Tuskegee National Forest (4,554 ha), which had very low pig activity and served as our reference area. The treatment area was a 4,515-ha property located in Bullock County, AL. Wildlife management practices focused on maintaining healthy whitetailed deer and eastern wild turkey (Meleagris gallopavo silvestris) populations. The most common habitat types were mixed pine (Pinus spp.)-hardwood forest and ripar- ian hardwoods. The canopy was primarily composed of sweetgum (Liquidambar styraciflua L.), loblolly pine (Pinus taeda L.), and southern shagbark hickory [Carya carolinaeseptentrionalis (Ashe) Engl. \& Graebn.], and the understory was mainly herbaceous and semi-woody species, such as blackberry (Rubus spp.), American beautyberry (Callicarpa americana L.), and eastern baccharis (Baccharis halimifolia L.). Wild pigs were present throughout the property, and camera surveys (conducted as part of a larger study) estimated the density to be 15.5 pigs $\mathrm{km}^{-2}$, which is much greater than the average density of 6-8 pigs $\mathrm{km}^{-2}$ in the southeastern United States (Lewis et al., 2019). The reference area was located approximately $25 \mathrm{~km}$ from the treatment area. The areas were similar in terms of stream gradient, forest cover and habitat type, and stream size. Although wild pigs were present in some areas of Tuskegee National Forest, they were not established in the area selected for the study. We confirmed this with camera surveys conducted in March 2018.

Sampling sites (watersheds) at the treatment and reference areas were selected if they met the following criteria: low gradient, occupied by deciduous wetland forests, and streams third order or lower in magnitude. Both study areas were located in the Upper Coastal Plain physiographic region and in the Mantachie-Iuka-Bibb soil association. We selected 11 watersheds at the treatment area and three watersheds at the reference area as sampling sites. The main tributaries were perennial, whereas most of the lower-order streams were intermittent, with flow only in winter and spring. At the treatment area, damage as a result of pig activity (rooting, digging, and wallowing) was observed at all sampling sites. This activity was observed on the floodplains and within the stream channels, even when the channels were dry.

\section{2 | Collection and analysis of water samples}

Sampling began in May 2018 at the treatment sites and in December 2018 at the reference sites and continued through June 2019. Water samples were collected from each site ( $n$ $=14$ ) every $2 \mathrm{wk}$ throughout the year as long as flow was present. Sampling events at the treatment and reference areas occurred within $24 \mathrm{~h}$ of each other. At each site, a 500-ml grab sample was collected in the middle of the channel at the outlet point where the main stream of the watershed flowed into the connecting tributary, thereby capturing the cumulative effect of wild pigs within the small watersheds. Discharge at the sampling location was measured using the USGS mechanical current-meter method (Turnipseed \& Sauer, 2010), in addition to DO, specific conductivity, temperature, and $\mathrm{pH}$.

Water samples were kept on ice and transported to the Auburn University Biogeochemistry Laboratory where they were stored at $4{ }^{\circ} \mathrm{C}$. Ion chromatography (Dionex ICS-1500, 
Thermo Fisher Scientific) was used to measure concentrations $\left(\mathrm{mg} \mathrm{L}^{-1}\right)$ of anions $\left(\mathrm{NO}_{2}{ }^{-}, \mathrm{NO}_{3}{ }^{-}, \mathrm{SO}_{4}{ }^{2-}, \mathrm{PO}_{4}{ }^{3-}\right)$ and cations $\left(\mathrm{NH}_{4}{ }^{+}, \mathrm{K}^{+}, \mathrm{Mg}^{2+}, \mathrm{Ca}^{2+}\right)$. Dissolved organic $\mathrm{C}(\mathrm{DOC})$ and total $\mathrm{N}(\mathrm{TN})$ concentrations $\left(\mathrm{mg} \mathrm{L}^{-1}\right)$ were measured using high-temperature combustion techniques (Shimadzu TOCVCPN, Shimadzu Scientific Instruments). Concentrations of total suspended solids (TSS) were determined using filtration methods in accordance with USEPA guidelines (USEPA, 1999). Discharge and nutrient concentrations were multiplied to obtain instantaneous loads in milligrams per second $\left(\mathrm{mg} \mathrm{s}^{-1}\right)$.

\section{3 | Analysis of fecal bacteria}

Water samples for E. coli analysis were taken from the grab samples immediately after collection. Three 1-ml subsamples were pipetted from each grab sample into vials containing Coliscan Easygel (Micrology Laboratories). The contents of each vial were transferred to petri dishes $(n=3)$ and incubated at $29-37{ }^{\circ} \mathrm{C}$ for $30 \mathrm{~h}$. After incubation, colony-forming unit (cfu) counts were conducted using a microscope to aid in the identification of colony type by medium color (purple/blue for $E$. coli and pink/red for FC). The mean cfu for each water sample was calculated and multiplied by $100 \mathrm{ml}$ to obtain the concentrations of $E$. coli and FC, in units of cfu $100 \mathrm{ml}^{-1}$. Fecal bacteria concentrations were multiplied by discharge to obtain instantaneous loads in cfu per second.

Microbial source tracking (MST) techniques using swine fecal bacteroidetes were used to determine if feces from wild pigs were entering the watersheds (Okabe et al., 2007). Additional water samples (one per site and collected using the method previously described) were collected during five sampling events: June 2018, July 2018, December 2018, April 2019, and August 2019. The samples were sent to a private laboratory (Source Molecular) to test for the presence of swine fecal bacteroidetes using quantitative polymerase chain reaction. Upon arrival, each water sample was filtered through a $0.45-\mu \mathrm{m}$ membrane filter, which was then placed in a 2$\mathrm{ml}$ tube containing beads and a lysis buffer. The sample was homogenized for 1 min and DNA extracted using a DNA-EZ ST1 extraction kit (GeneRite). Amplifications to detect the target gene biomarker were run on a StepOnePlus real-time thermal cycler (Applied Biosystems) in a final reaction volume of $20 \mu \mathrm{l}$ sample extract, forward primer, reverse primer, probe, and an optimized buffer. All assays were run in duplicate, and quantification was achieved by extrapolating target gene copy numbers from a standard curve generated from serial dilutions of known gene copy numbers. A positive and negative control were run alongside the samples to identify any false negatives or positives (Source Molecular, personal communication, 2019).

\subsection{Statistical analysis}

Statistical analyses were conducted using $\mathrm{R}$ statistical platform version 3.5.3 (R Core Team, 2019). Homoscedasticity and normality of the residuals were assessed visually with diagnostic graphs and statistically using Shapiro-Wilk and Levene's tests. Data that did not meet assumptions of normality were natural $\log$ transformed.

Linear mixed effects analysis was used to account for temporal autocorrelation and for the confounding relationship between presence of wild pigs (treatment type) and study area. Models were developed using the lme4 (Bates, Mächler, Bolker, \& Walker, 2015) and lmerTest (Kuznetsova et al., 2017) packages to assess the importance of treatment type, season, and discharge in explaining water quality and fecal bacteria at the two study areas. For concentrations, a complete model was built with the fixed effects of Treatment Type (wild pigs or reference), Season (wet or dry), and Discharge, as well as interaction terms for Treatment Type $\times$ Season and Season $\times$ Discharge. Seasons were delineated by flow, which was greatest from November through April (wet season) and diminished from May through October (dry season). Discharge was included as a fixed effect to account for changes in nutrient and fecal bacteria concentrations due to fluctuations in stream flow. A random effect of Stream was included to account for inherent differences among watersheds and sampling areas. Additionally, a random effect of Time (day nested within month) was added to account for temporal autocorrelation as a result of repeated sampling (Chaves, 2010). The complete model for instantaneous loads included Treatment Type, Season, an interaction term for Treatment Type $\times$ Season, and the random effects of Stream and Time.

A step-down model-building approach was used via the step function in the lmerTest package to eliminate nonsignificant $(\alpha>.05)$ fixed effects and interaction terms, resulting in a final model for each water quality and fecal bacteria variable. Nonsignificant fixed effects were left in the model if interaction terms containing the effects were significant. Akaike's Information Criterion corrected for small sample size was used to further evaluate models and confirm that the final model best fit the data.

\section{3 | RESULTS}

Fourteen streams were sampled from May 2018 to June 2019 during 16 sampling events that occurred during flow periods at bimonthly intervals. Each stream was sampled at least four times. Flow ceased at the end of July 2018 due to low rainfall, and flowing water did not return until December 2018. A drought from mid-May 2019 to mid-October 2019 meant that the majority of streams were dry or only contained 
stagnant pools of water and therefore were unable to be sampled.

\section{1 | Model selection}

The fixed effect of treatment type was significant in linear mixed effects models for specific conductivity and concentrations of $\mathrm{SO}_{4}{ }^{2-}, \mathrm{Ca}^{2+}, \mathrm{TN}$, and DOC (Table 1). An interaction term for Treatment Type $\times$ Season was significant in models for $\mathrm{Mg}^{2+}$ and $\mathrm{NO}_{2}{ }^{-}$concentrations. None of the fixed effects or interaction terms was significant for $\mathrm{pH}$ or $\mathrm{PO}_{4}{ }^{3-}$ and therefore were excluded from the models. The effect of Treatment Type was significant in the model for $E$. coli but not significant for FC. An interaction term for Treatment Type $\times$ Season was included in the FC model. For instantaneous loads, Treatment Type was significant for $\mathrm{NO}_{3}{ }^{-}$, TN, DOC, and FC models. An interaction term for Treatment Type $\times$ Season was significant for $\mathrm{NO}_{2}{ }^{-}$, TN, DOC, E. coli, and FC instantaneous loads.

\section{2 | Water quality}

Discharge was generally greater at reference watersheds than at treatment watersheds (Table 2), although stormflow conditions resulted in considerable variation in discharge rates. The concentration of DOC in treatment watersheds was 10.62 $\mathrm{mg} \mathrm{L}^{-1}$ greater than in reference watersheds $(p<.001)$, with median concentrations of 17.83 and $4.51 \mathrm{mg} \mathrm{L}^{-1}$, respectively. Treatment watersheds had 2.35 times the TN concentration of reference watersheds $(p=.01)$. Concentrations of $\mathrm{NO}_{2}{ }^{-}, \mathrm{NO}_{3}{ }^{-}$, and $\mathrm{NH}_{4}{ }^{+}$did not significantly differ between treatment types $(p>.05)$, although $\mathrm{NO}_{3}{ }^{-}$concentration in the dry season was 0.1 times the concentration in the wet season $(p=.004)$.

Specific conductivity was affected by treatment type and discharge. At treatment watersheds, specific conductivity was 3.35 times the specific conductance at reference watersheds $(p<.001)$. Concentrations of $\mathrm{SO}_{4}{ }^{2-}$ were affected by treatment type, season, and discharge, whereas $\mathrm{Ca}^{2+}$ was affected by treatment type and discharge. Treatment watersheds had 10.25 times the $\mathrm{SO}_{4}{ }^{2-}$ concentration in reference watersheds $(p<.001)$ and 4.84 times the $\mathrm{Ca}^{2+}$ concentration $(p<.001)$. Median $\mathrm{PO}_{4}{ }^{3-}$ concentrations were $0 \mathrm{mg} \mathrm{L}^{-1}$ at both treatment and reference watersheds and did not differ by treatment type, season, or discharge. Dissolved oxygen differed by season and discharge but not by treatment type. For every $1 \%$ increase in discharge, DO increased by $4.74 \times 10^{-3} \mathrm{mg} \mathrm{L}^{-1}$ $(p<.001)$. Concentration of TSS was affected by discharge but not by treatment type or season. Reference watersheds had greater instantaneous loads of $\mathrm{NO}_{3}{ }^{-}(p=.03), \mathrm{TN}(p=.01)$, and DOC $(p=.04)$ than treatment watersheds.

\section{3 | Fecal bacteria}

Treatment watersheds had 40.4 times the $E$. coli concentrations of reference watersheds $(p<.001)$. Concentrations ranged from 0 to $70,767.00 \mathrm{cfu} 100 \mathrm{ml}^{-1}$ at treatment watersheds and from 0 to $967.00 \mathrm{cfu} 100 \mathrm{ml}^{-1}$ at reference watersheds. Escherichia coli concentrations varied by treatment type and individual watershed (Figure 1). Fecal coliform concentrations ranged from $1,133.00$ to $388,767.00 \mathrm{cfu} 100 \mathrm{ml}^{-1}$ at treatment watersheds and from 500.00 to $27,433.00 \mathrm{cfu} 100$ $\mathrm{ml}^{-1}$ at reference watersheds and were not statistically different between treatments ( $p=.15$; Figure 2).

Instantaneous loads of $E$. coli ranged from 0 to $19,775,561.10 \mathrm{cfu} \mathrm{s}^{-1}$ at treatment watersheds and from 0 to $18,436.03 \mathrm{cfu} \mathrm{s}^{-1}$ at reference watersheds. Differences in $E$. coli loads between treatment types were not significant ( $p$ $=.73$ ). At treatment watersheds, instantaneous loads of FC ranged from 39.71 to $30,941,723.00 \mathrm{cfu} \mathrm{s}^{-1}$, whereas loads at reference watersheds ranged from 3162.39 to 3,686,263.00 $\mathrm{cfu} \mathrm{s}^{-1}$. Instantaneous loads at reference watersheds were 80.92 times the loads at treatment watersheds $(p<.001)$.

A total of 38 samples from the 14 watersheds were sent for DNA analysis of swine fecal biomarkers from five different sampling events (Table 3). Overall, DNA from swine fecal bacteroidetes was detected in 23 of $33(69.7 \%)$ samples from treatment watersheds and in 0 of $5(0.0 \%)$ samples from reference watersheds. Biomarker concentrations were quantified in 16 of $23(69.6 \%)$ samples, whereas the remaining seven samples had concentrations below the limit of quantification. Quantified concentrations ranged from 361 to 19,200 copies $100 \mathrm{ml}^{-1}$, with an overall mean of 4,070 copies $100 \mathrm{ml}^{-1}$. Although some samples from treatment watersheds tested negative, each of the 11 treatment watersheds tested positive for swine fecal bacteroidetes at least once during the course of the study.

\section{4 | DISCUSSION}

\section{1 | Water quality}

Concentrations of DOC and TN (organic and inorganic) were elevated at the treatment watershed compared with the reference watershed; however, concentrations of $\mathrm{NO}_{2}{ }^{-}, \mathrm{NO}_{3}{ }^{-}$, and $\mathrm{NH}_{4}{ }^{+}$were not elevated. Organic $\mathrm{N}$ content was likely elevated, which in turn increased $\mathrm{TN}$ concentrations. Inorganic $\mathrm{N}$ levels may not have been elevated due to low DO levels in the dry season. The transformation of $\mathrm{NH}_{4}{ }^{+}$to $\mathrm{NO}_{2}{ }^{-}$is the rate-limiting step of nitrification and is slowed when oxygen is not readily available. Wild pig feces and urine likely contributed to the increased levels of organic $\mathrm{C}$ and $\mathrm{N}$ in the treatment watersheds because reference watersheds were similar in geomorphology, hydrology, and habitat type. Singer 


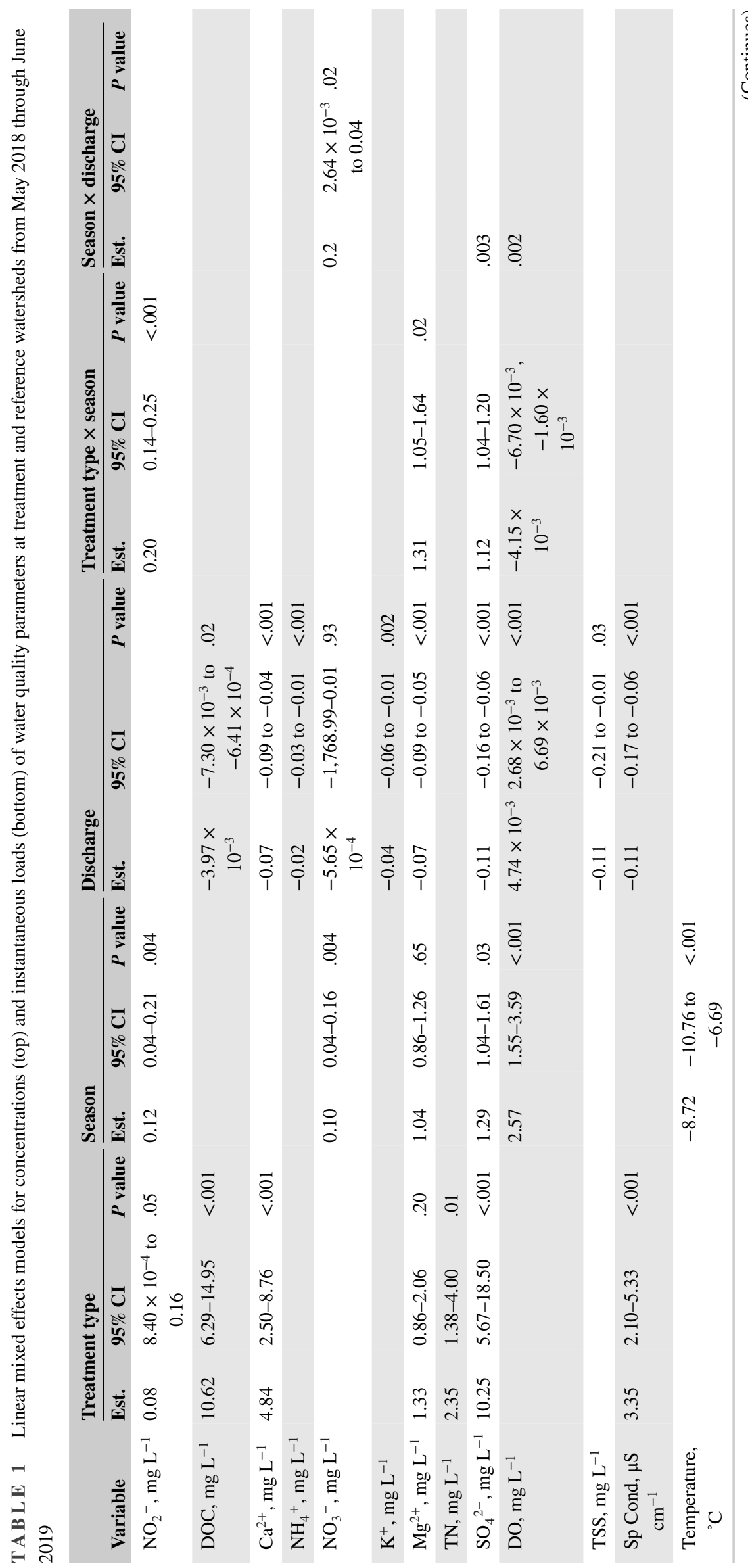




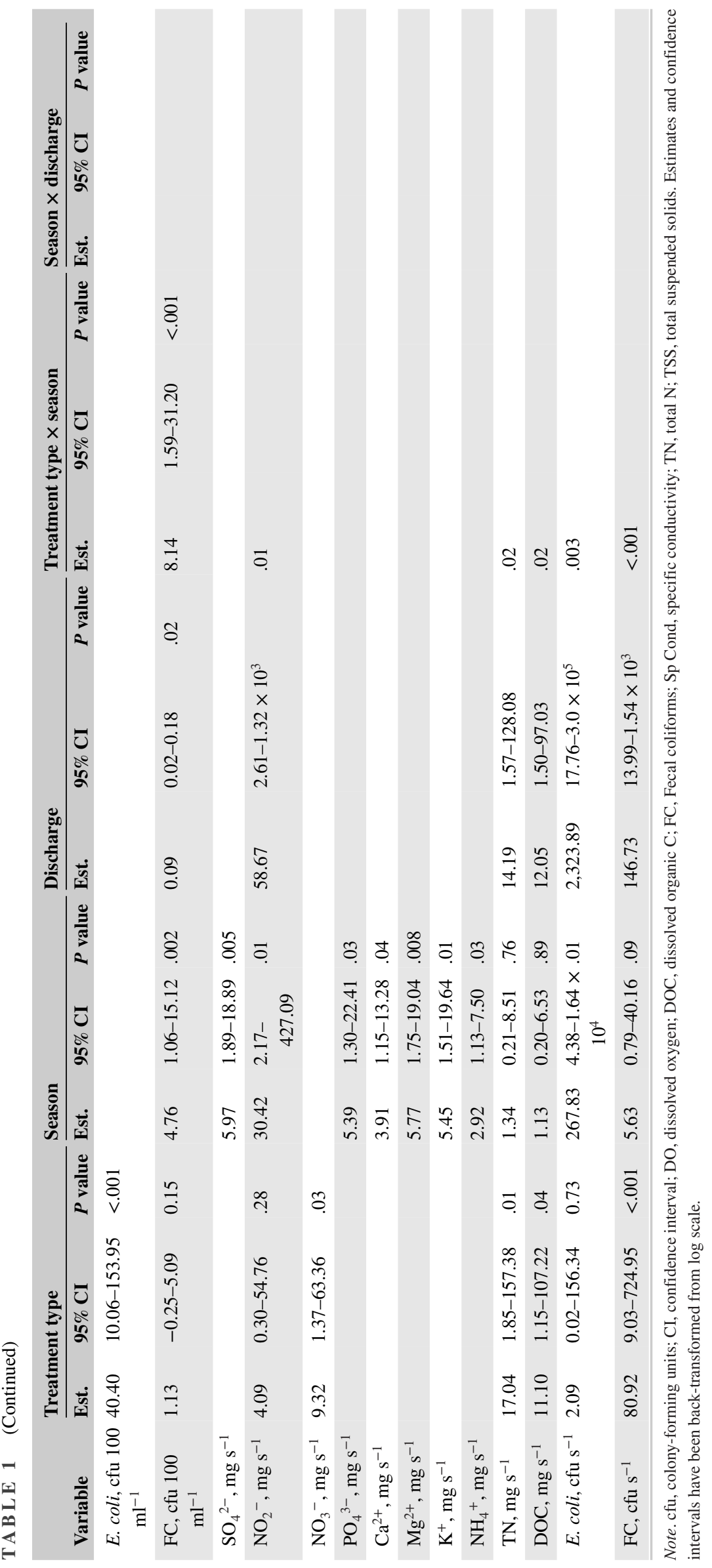


T A B L E 2 Summary of water quality concentrations and instantaneous loads for treatment and reference watersheds from May 2018 through June 2019

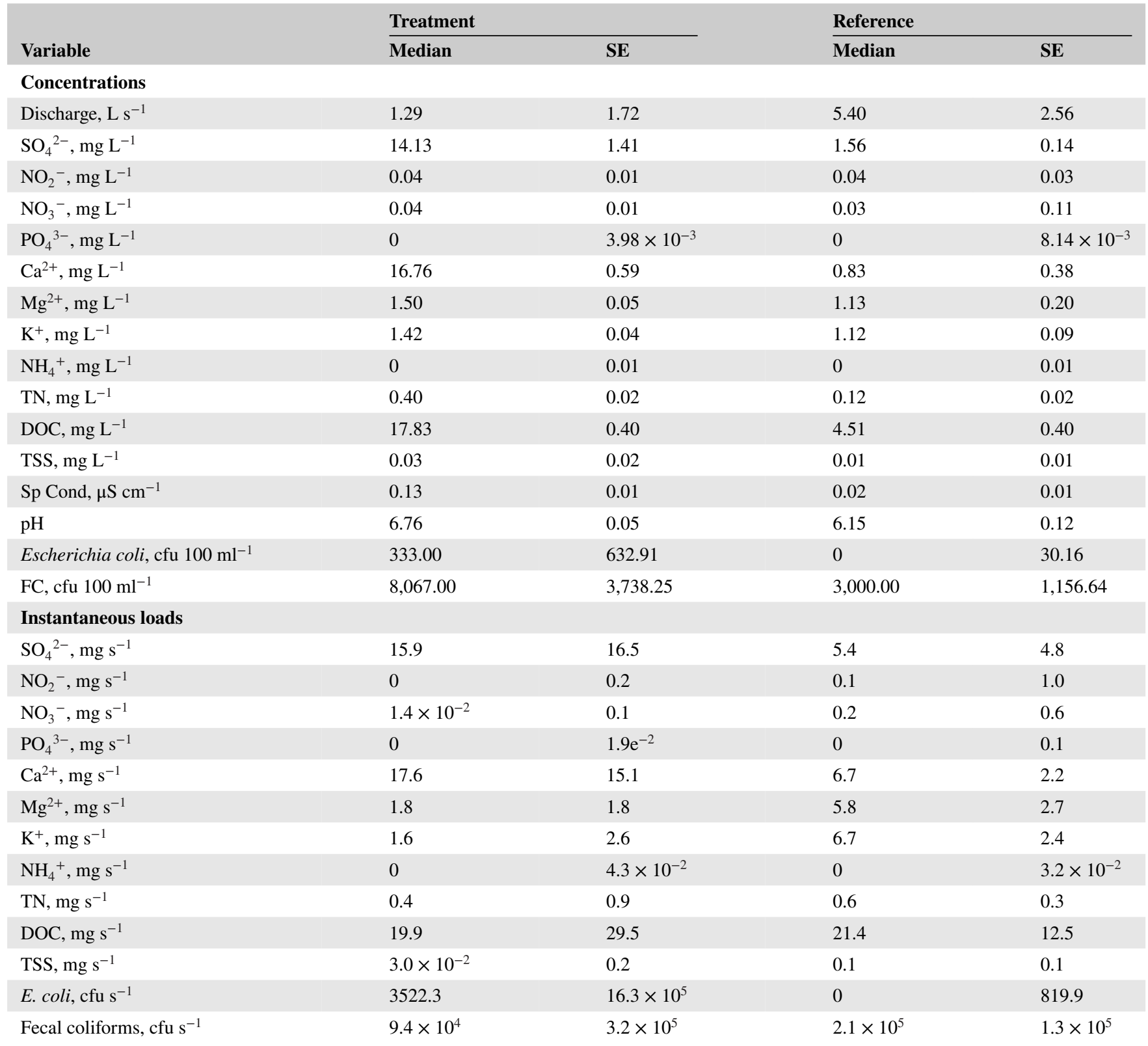

Note. DOC, dissolved organic C; FC, fecal coliforms; Sp Cond, specific conductivity; TN, total N; TSS, total suspended solids.

et al. (1984) found numerically greater annual N concentrations in stream water from an area with rooting activity; however, statistical comparison between treatment types in that study was not performed because drought conditions reduced the number of samples collected. Increased precipitation and stormflow during the wet season could have transported nutrients and organic material from the floodplain into the watershed, resulting in elevated $\mathrm{N}$ concentrations in stream water. The geomorphology and hydrology of the two sampling locations was not described in the Singer et al. (1984) study, but differences in slope, substrate, basin shape, watershed size, and stream flow could have contributed to different $\mathrm{N}$ concentrations in stream water. In comparison, Brooks et al. (2020) did not find a link between runoff from wild pigs and $\mathrm{N}$ in stream water. However, the animals in that study were in a pen and did not have access to the stream, and riparian vegetation acted as a buffer for pen runoff. Other factors present in the study area likely influenced $\mathrm{N}$ and other nutrient levels in the stream, including the presence of livestock, agriculture, and construction.

Dissolved oxygen did not significantly differ between treatment types but differed by season and stream discharge. Across watersheds and treatments, DO was lower in the dry season and positively correlated with discharge. Dissolved oxygen content is affected by several factors, including water temperature, flow, photosynthesis, and microbial 


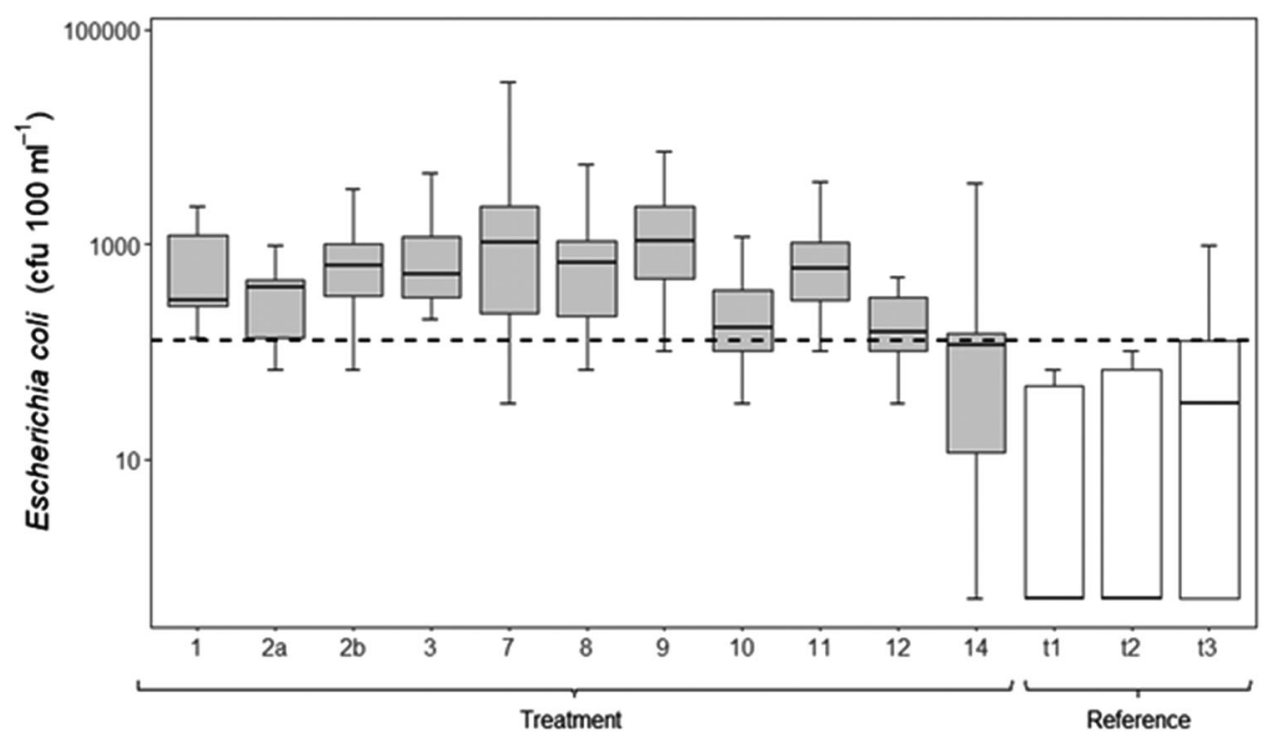

F I G U R E 1 Escherichia coli concentrations for treatment and reference watersheds from May 2018 through June 2019. The dashed line indicates

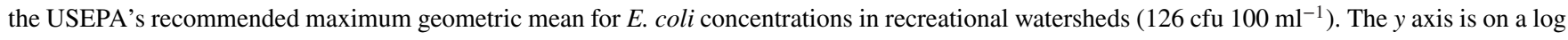
scale

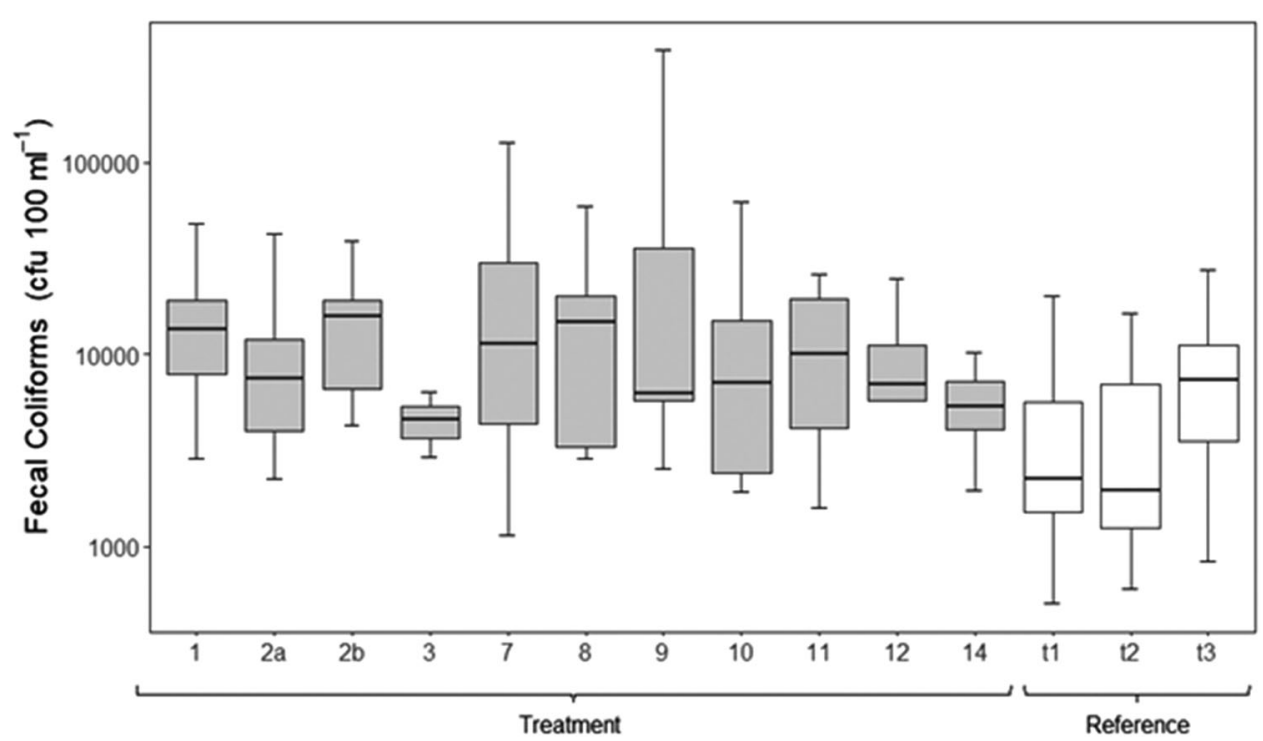

F I G U R E 2 Fecal coliform concentrations for treatment and reference watersheds from May 2018 through June 2019. The $y$ axis is on a log scale

decomposition of organic material. Although disturbance (i.e., rooting) and introduction of animal waste in the aquaticterrestrial interface can increase organic material in a stream and thereby increase microbial consumption of DO, we did not find significantly lower levels of DO in watersheds with wild pigs. We speculate that the watersheds included in this study had little to no riparian vegetation buffer between the floodplain and the stream channel, so there was very little plant matter that could be transported into the aquatic environment by rooting activity. We attribute the elevated DOC and $\mathrm{TN}$ in the treatment watersheds to wild pig feces, which suggests that microbial consumption of DO increased in order to decompose the increased amount of organic matter. The fact that we did not detect a decrease in DO levels could be due to spatial and temporal variability in the watersheds and wild pig usage of these habitats, especially if the change was subtle. A larger sample size and more intensive sampling may be needed to observe changes in DO levels resulting from wild pig activity. Doupé et al. (2010) reported lower DO in ephemeral lagoons accessible to wild pigs; however, the lagoons significantly differed in plant, macroinvertebrate, and fish species composition, all of which are factors that can affect DO levels. Additionally, they sampled during the dry season, which is when water levels, and subsequently DO, continuously decrease because there is no replenishment from rainfall or runoff.

Specific conductivity, $\mathrm{Ca}^{2+}$, and $\mathrm{SO}_{4}{ }^{2-}$ were greater in the treatment watersheds but differed by season and/or 
TA B L E 3 Results from DNA analysis of swine fecal biomarkers in water samples collected at treatment and reference watersheds during 2018-2019

\begin{tabular}{|c|c|c|c|c|c|}
\hline Treatment watershed & June 2018 & July 2018 & December 2018 & April 2019 & August 2019 \\
\hline & \multicolumn{5}{|c|}{$\longrightarrow$ copies $100 \mathrm{ml}^{-1} \longrightarrow$} \\
\hline 1 & ND & DNQ & 569 & - & - \\
\hline $2 \mathrm{~A}$ & DNQ & $-^{\mathrm{a}}$ & 18,300 & 692 & - \\
\hline 2B & ND & - & 19,200 & ND & - \\
\hline 3 & DNQ & ND & 826 & - & - \\
\hline 7 & ND & - & 666 & - & - \\
\hline 8 & 361 & ND & 5,210 & ND & - \\
\hline 9 & 3,540 & - & 1,290 & - & - \\
\hline 10 & ND & - & 1,900 & DNQ & - \\
\hline 11 & 577 & - & 10,500 & 622 & - \\
\hline 12 & ND & ND & 619 & DNQ & - \\
\hline 14 & DNQ & - & 1,050 & DNQ & - \\
\hline \multicolumn{6}{|l|}{ Reference } \\
\hline $\mathrm{T} 1$ & - & - & - & ND & ND \\
\hline $\mathrm{T} 2$ & - & - & - & ND & - \\
\hline $\mathrm{T} 3$ & - & - & - & ND & ND \\
\hline Detections/total & $6 / 11$ & $1 / 4$ & $11 / 11$ & $5 / 7 ; 0 / 3$ & $0 / 2$ \\
\hline
\end{tabular}

Note. DNQ, detected not quantified (concentration below limit of quantification); ND, not detected.

a Samples were not analyzed from this watershed.

discharge. Sulfur is released during the decomposition of organic material and oxidized to $\mathrm{SO}_{4}{ }^{2-}$, so wild pig feces could have increased $\mathrm{SO}_{4}{ }^{2-}$ in the treatment watersheds. However, conductivity, $\mathrm{Ca}^{2+}$, and $\mathrm{SO}_{4}{ }^{2-}$ are strongly influenced by soil type and subsurface geology, and differences in concentrations are most likely due to geologic and soil morphologic variability. Greater $\mathrm{Ca}^{2+}$ concentrations at the treatment watersheds may be attributed to subsurface marine deposits referred to as the Selma Chalk region, which does not run under the reference watersheds. A possible reason for the difference in $\mathrm{SO}_{4}{ }^{2-}$ concentrations between the treatment and reference watersheds is the original water source. The treatment watersheds may be fed more by underground springs or may not be in comparison to the reference watersheds. Groundwater erodes and dissolves rock and minerals over time, which introduces $\mathrm{SO}_{4}{ }^{2-}$ ions to the aquifer (USEPA, 2003). Conductivity reflects the concentration of ions present (USEPA, 2012b), so elevated specific conductivity at treatment watersheds is a function of greater $\mathrm{Ca}^{+}$and $\mathrm{SO}_{4}{ }^{2-}$ concentrations.

Although wild pig rooting was regularly observed within and adjacent to the stream channel, there was no difference between TSS concentrations in treatment and reference watersheds. The soils at both locations were mainly composed of sandy bedloads, which means sediment particles drop quickly out of the water column and are not suspended for long. This is likely why $\mathrm{PO}_{4}{ }^{3-}$ was not elevated despite the input of fecal material and urine from wild pigs, as it binds quickly to sediment particles (Søndergaard, Jensen, \& Jeppesen, 2003). Also, there was little to no overland runoff crossing the terrestrial-aquatic interface because the floodplains at all watersheds were relatively flat. Although we did not detect a difference in TSS between treatments in this study, other watersheds with different geomorphological and hydrological features (i.e., V-shaped catchment with clay substrate) could show more pronounced differences. Dunkell, Bruland, Evensen, \& Litton (2011) and Strauch et al. (2016) did not find a significant difference in TSS in runoff from fenced and unfenced plots with wild pig presence. However, plot size was small $(10 \mathrm{~m}$ by $5 \mathrm{~m}$ ) in comparison to the amount of soil that wild pigs can disturb, and unfenced plots may not have experienced the intensity of rooting typical for the area. Water samples were only taken from stormflow runoff, which can highlight extreme values and does not reflect water quality under normal conditions.

Unlike nutrient concentrations, instantaneous loads for $\mathrm{TN}, \mathrm{NO}_{3}{ }^{-}$, and DOC were greater at reference watersheds than at treatment watersheds. However, reference watersheds typically had greater discharge, especially during times of increased precipitation and decreased evapotranspiration, and therefore nutrient loads were greater despite low concentrations. Additionally, much of the load data were highly variable due to differences in discharge, which made it difficult to detect differences between treatment types. 


\section{2 | Fecal bacteria}

There were stark differences in $E$. coli concentrations between the two watershed treatment types. The USEPA recommends that recreational watersheds have a maximum geometric mean concentration of $126 \mathrm{cfu} 100 \mathrm{ml}^{-1}$ in a 30-d sampling period and that no more than $10 \%$ of samples taken have a concentration greater than the statistical threshold value of 410 cfu $100 \mathrm{ml}^{-1}$ (USEPA, 2012a). All treatment watersheds had mean $E$. coli concentrations that exceeded $126 \mathrm{cfu} 100 \mathrm{ml}^{-1}$, whereas the reference watersheds were below this threshold. Median E. coli concentrations at the treatment watersheds were similar to those measured in nearby urban watersheds (Crim, Schoonover, \& Lockaby, 2012), despite the lack of surface runoff from developed areas and other anthropogenic sources at our study sites. Treatment and reference watersheds both lacked livestock and had the same wildlife species (and sources of fecal matter) except for wild pigs; therefore, the elevated $E$. coli concentrations at the treatment watersheds were likely a result of wild pig activity.

Unlike $E$. coli, FC concentrations did not vary by treatment type and were elevated in comparison to nearby urban watersheds (Crim, Schoonover, \& Lockaby, 2012). Although instantaneous loads of FC were greater at reference watersheds, this can be attributed to greater discharge rates, as previously mentioned. Fecal coliform concentrations historically were used to predict the presence of gastrointestinal illness-causing pathogens, but the USEPA no longer uses FC as an indicator of fecal contamination (USEPA, 2012a). Escherichia coli and enterococci are now the preferred method of identifying bodies of water potentially contaminated by fecal material because their presence unequivocally indicates the occurrence of fecal contamination even if the detected strains are nonpathogenic (Edberg, Rice, Karlin, \& Allen, 2000). Fecal coliform testing also detects thermotolerant nonfecal ("environmental") coliform bacteria and can lead to an overestimation of fecal contamination and risk to public health (Francy, Myers, \& Metzker, 1993). In our study, it is likely that environmental coliform bacteria were naturally present in runoff and streams and incubated along with FC, which made it difficult to detect an effect of wild pig presence on FC concentrations. Previous studies examining the impacts of wild pigs on fecal contamination of watersheds have reported mixed results. Kaller and Kelso (2003) reported positive correlation of wild pig presence with fecal bacteria, but they measured FC, and sampling occurred only three times in one watershed basin. Dunkell, Bruland, Evensen, and Walker (2011) and Strauch et al. (2016) did not find a significant effect of wild pigs on E. coli, enterococci, or total coliforms in runoff from fenced and unfenced plots, but, as mentioned previously, plot sizes were small, and unfenced plots may not have experienced typical rooting intensity. Brooks et al. (2020) did not detect a difference in E. coli and ente- rococci concentrations between pen runoff and nearby stream water, which is likely because wild pigs did not have direct access to the stream and because there were other sources of fecal matter in the area, such as livestock and human waste.

The positive detection of swine fecal bacteroidetes in treatment watersheds via MST and the absence of same in reference watersheds further indicate that wild pigs can introduce fecal material and disease-causing pathogens to streams. The effects of fecal contamination are not limited to the initial source area: downstream areas may be affected as well. Water-borne bacteria and pathogens accumulate as low-order streams flow into main tributaries of increasing magnitude. Stream sediments also serve as a reservoir for $E$. coli and potentially other pathogens (Garzio-Hadzick et al., 2010), and disturbance events that affect stream sediment (e.g., stormflow, anthropogenic activities, wild pig rooting) could resuspend these microorganisms in the water column and cause them to travel farther downstream or come into contact with a susceptible human or animal. Reducing wild pig presence in riparian areas during times of potential disturbance could reduce the amount of fecal contamination in the watershed and thereby decrease the $E$. coli deposited in stream sediment. To our knowledge, this study is the first that definitively links wild pig presence to the introduction of fecal material and waterborne pathogens in watersheds and meets the four conditions previously mentioned that are needed for an accurate assessment of wild pig impacts on water quality.

\section{5 | CONCLUSION}

This study shows that wild pigs are a threat to water quality in forested watersheds by introducing fecal material and potentially disease-causing organisms. Further research on the downstream fate of pathogens and potential sources of contact with humans and animals is necessary for a clear understanding of the impacts wild pigs have on local water quality and ecosystem health. Our results suggest that MST and $E$. coli monitoring may be effective ways to gauge wild pig activity in watersheds and indicate that it may be important to control wild pig populations upstream of major drinking water sources and recreational areas.

\section{ACKNOWLEDGMENTS}

The authors thank USDA/APHIS/Wildlife Services for funding and logistical support as well as the project technicians, research associates, and volunteers, and landowners involved in the study.

\section{AUTHOR CONTRIBUTIONS}

Sara A. Bolds, Conceptualization, Data curation, Formal analysis, Investigation, Methodology, Visualization, Writingoriginal draft, Writing-review \& editing; Graeme Lockaby, 
Conceptualization, Funding acquisition, Methodology, Project administration, Supervision, Validation, Visualization, Writing-review \& editing; Stephen S. Ditchkoff, Conceptualization, Funding acquisition, Methodology, Project administration, Supervision, Validation, Visualization, Writing-review \& editing; Mark D. Smith, Conceptualization, Funding acquisition, Project administration, Writing-review \& editing; Kurt C. VerCauteren, Funding acquisition, Resources, Writing-review \& editing.

\section{CONFLICT OF INTEREST}

The authors declare no conflict of interest.

\section{O R C I D}

Sara A. Bolds @ https://orcid.org/0000-0003-3779-0029

\section{R E F E R E N C E S}

Ackers, M., Mahon, B. E., Leahy, E., Goode, B., Damrow, T., Hayes, P. S., Bibb, W. F., Rice, D. H., Barrett, T. J., Hutwagner, L., Griffin, P. M., \& Slutsker, L. (1998). An outbreak of Escherichia coli O157:H7 infections associated with leaf lettuce consumption. Journal of Infectious Diseases, 177(6), 1588-1593. https://doi.org/10.1086/515323

Atwill, E. R., Sweitzer, R. A., Pereira, M., Gardner, I. A., Van Vuren, D., \& Boyce, W. M. (1997). Prevalence of and associated risk factors for shedding Cryptosporidium parvum oocysts and Giardia cysts within feral pig populations in California. Applied and Environmental Microbiology, 63(10), 3946-3949.

Baldwin, A. H., \& Batzer, D. P. (2012). Wetland habitats of North America: An introduction. In D. P. Batzer \& A. H. Baldwin (Eds.), Wetland habitats of North America (pp. 1-9). University of California Press.

Baldwin, A. H., \& Pendleton, F. N. (2003). Interactive effects of animal disturbance and elevation on vegetation of a tidal freshwater marsh. Estuaries, 26(4A), 905-915. https://doi.org/10.1007/BF02803349

Bates, D., Mächler, M., Bolker, B. M., \& Walker, S. C. (2015). Fitting linear mixed-effects models using lme4. Journal of Statistical Software, 67(1). https://doi.org/10.18637/jss.v067.i01

Beasley, J. C., Ditchkoff, S. S., Mayer, J. J., Smith, M. D., \& Vercauteren, K. C. (2018). Research priorities for managing invasive wild pigs in North America. Journal of Wildlife Management, 82(4), 674-681. https://doi.org/10.1002/jwmg.21436

Bracke, M. B. M. (2011). Review of wallowing in pigs: Description of the behaviour and its motivational basis. Applied Animal Behaviour Science, 132(1-2), 1-13. https://doi.org/10.1016/j.applanim.2011.01. 002

Brooks, J. P., Smith, R. K., Aldridge, C. A., Chaney, B., Omer, A., Dentinger, J., Street, G. M., \& Baker, B. H. (2020). A preliminary investigation of wild pig (Sus scrofa) impacts in water quality. Journal of Environmental Quality, 49, 27-37. https://doi.org/10.1002/jeq2. 20036

Chalkowski, K., Lepczyk, C. A., \& Zohdy, S. (2018). Parasite ecology of invasive species: Conceptual framework and new hypotheses. Trends in Parasitology, 34(8), 655-663. https://doi.org/10.1016/j.pt.2018.05. 008

Chaves, L. F. (2010). An entomologist guide to demystify pseudoreplication: Data analysis of field studies with design constraints. Journal of Medical Entomology, 47(3), 291-298. https://doi.org/10.1603/ ME09250
Crim, J. F., Schoonover, J. E., \& Lockaby, B. G. (2012). Assessment of fecal coliform and Escherichia coli across a land cover gradient in west Georgia streams. Water Quality, Exposure and Health, 4, 143158. https://doi.org/10.1007/s12403-012-0073-Z

Cushman, J. H., Tierney, T. A., \& Hinds, J. M. (2004). Variable effects of feral pig disturbances on native and exotic plants in a California grassland. Ecological Applications, 14(6), 1746-1756. https://doi.org/10. 1890/03-5142

Davies-Colley, R. J., Nagels, J. W., Smith, R. A., Young, R. G., \& Phillips, C. J. (2004). Water quality impact of a dairy cow herd crossing a stream. New Zealand Journal of Marine and Freshwater Research, 38, 569-576. https://doi.org/10.1080/00288330.2004. 9517262

Doupé, R. G., Mitchell, J., Knott, M. J., Davis, A. M., \& Lymbery, A. J. (2010). Efficacy of exclusion fencing to protect ephemeral floodplain lagoon habitats from feral pigs (Sus scrofa). Wetlands Ecology and Management, 18, 69-78. https://doi.org/10.1007/s11273-0099149-3

Dunkell, D. O., Bruland, G. L., Evensen, C. I., \& Litton, C. M. (2011). Runoff, sediment transport, and effects of feral pig (Sus scrofa) exclusion in a forested Hawaiian watershed. Pacific Science, 65(2), 175194. https://doi.org/10.2984/65.2.175

Dunkell, D. O., Bruland, G. L., Evensen, C. I., \& Walker, M. J. (2011). Effects of feral pig (Sus scrofa) exclusion on enterococci in runoff from the forested headwaters of a Hawaiian watershed. Water, Air, and Soil Pollution, 221(1-4), 313-326. https://doi.org/10.1007/s11270011-0792-y

Edberg, S. C., Rice, E. W., Karlin, R. J., \& Allen, M. J. (2000). Escherichia coli: The best biological drinking water indicator for public health protection. Journal of Applied Microbiology, 88, 106S110S. https://doi.org/10.1111/j.1365-2672.2000.tb05338.x

Fogarty, L. R., Haack, S. K., Wolcott, M. J., \& Whitman, R. L. (2003). Abundance and characteristics of the recreational water quality indicator bacteria Escherichia coli and enterococci in gull faeces. Journal of Applied Microbiology, 94(5), 865-878. https://doi.org/10.1046/j. 1365-2672.2003.01910.x

Francy, D. S., Myers, D. N., \& Metzker, K. D. (1993). Escherichia coli and fecal-coliform bacteria as indicators of recreational water quality (Water-Resources Investigations Report 93-4083). USGS. https://doi. org/10.3133/wri934083

Garzio-Hadzick, A., Shelton, D. R., Hill, R. L., Pachepsky, Y. A., Guber, A. K., \& Rowland, R. (2010). Survival of manure-borne E. coli in streambed sediment: Effects of temperature and sediment properties. Water Research, 44(9), 2753-2762. https://doi.org/10.1016/j.watres. 2010.02.011

Gray, S. M., Roloff, G. J., Kramer, D. B., Etter, D. R., Vercauteren, K. C., \& Montgomery, R. A. (2020). Effects of wild pig disturbance on forest vegetation and soils. Journal of Wildlife Management, 84(4), 739-748. https://doi.org/10.1002/jwmg.21845

Hampton, J., Spencer, P. B. S., Elliot, A. D., \& Thompson, R. C. A. (2006). Prevalence of zoonotic pathogens from feral pigs in major public drinking water catchments in Western Australia. EcoHealth, 3(2), 103-108. https://doi.org/10.1007/s10393-006-0018-8

Henry, V. G., \& Conley, R. H. C. (1972). Fall foods of European wild hogs in the Southern Appalachians. Journal of Wildlife Management, 36(3), 854-860. https://doi.org/10.2307/3799440

Howe, T. D., \& Bratton, S. P. (1976). Winter rooting activity of the European wild boar in the Great Smoky Mountains National Park. Castanea, 41(3), 256-264. 
Jay, M. T., Cooley, M., Carychao, D., Wiscomb, G. W., Sweitzer, R. A., Crawford-Miksza, L., Farrar, J. F., Lau, D. K., O’Connell, J., Millington, A., Asmundson, R. V., Atwill, E. R., \& Mandrell, R. E. (2007). Escherichia coli $\mathrm{O} 157: \mathrm{H} 7$ in feral swine near spinach fields and cattle, central California coast. Emerging Infectious Diseases, 13(12), 1908-1911. https://doi.org/10.3201/eid1312.070763

Johnston, C. A. (2012). Beaver wetlands. In D. P. Batzer \& A. H. Baldwin (Eds.), Wetland habitats of North America (pp. 161-171). University of California Press.

Jolley, R. L., Lockaby, B. G., \& Governo, R. M. (2010). Vegetation nutrient dynamics associated with sedimentation in headwater riparian forests. Soil Science Society of America Journal, 74, 1389-1397. https://doi.org/10.2136/sssaj2009.0142

Kaller, M. D., \& Kelso, W. E. (2003). Effects of feral swine on water quality in a coastal bottomland stream. In Proceedings of the Annual Conference of the Southeastern Association of Fish and Wildlife Agencies (pp. 291-298). SEAFWA.

King, S. L., Battaglia, L. L., Hupp, C. R., Keim, R. F., \& Lockaby, B. G. (2012). Floodplain wetlands of the Southeastern Coastal Plain. In D. P. Batzer \& A. H. Baldwin (Eds.), Wetland habitats of North America: Ecology and conservation concerns (pp. 253-266). University of California Press.

Kuznetsova, A., Brockhoff, P. B., \& Christensen, R. H. B. (2017). lmerTest package: Tests in linear mixed effects models. Journal of Statistical Software, 82(13). https://doi.org/10.18637/jss.v082.i13

Lewis, J. S., Corn, J. L., Mayer, J. J., Jordan, T. R., Farnsworth, M. L., Burdett, C. L., ... Miller, R. S. (2019). Historical, current, and potential population size estimates of invasive wild pigs (Sus scrofa) in the United States. Biological Invasions, 21(7), 2373-2384. https: //doi.org/10.1007/s10530-019-01983-1

Lindqvist, A., Jo, B., So, A., Lindberg, A., Ulander, S. B., Lo, S., VerCauteren, K. C., Sweeney, S. J., \& Andersson, Y. (2008). A large Escherichia coli $\mathrm{O} 157$ outbreak in Sweden associated with locally produced lettuce. Foodborne Pathogens and Disease, 5(3), 339-349. https://doi.org/10.1089/fpd.2007.0065

Line, D. E., Harman, W. A., Jennings, G. D., Thompson, E. J., \& Osmond, D. L. (2000). Nonpoint-source pollutant load reductions associated with livestock exclusion. Journal of Environmental Quality, 29(6), 1882-1890. https://doi.org/10.2134/jeq2000. $00472425002900060022 x$

Maret, T. J., Parker, M., \& Fannin, T. E. (1987). The effect of beaver ponds on the nonpoint source water quality of a stream in southwestern Wyoming. Water Research, 21(3), 263-268. https://doi. org/10.1016/0043-1354(87)90204-1

Mayer, J. J., Beasley, J. C., Boughton, R. K., \& Ditchkoff, S. S. (2020). Wild pigs in southeastern North America. In K. C. VerCauteren, J. C. Beasley, S. S. Ditchkoff, J. J. Mayer, G. J. Roloff, \& B. K. Strickland (Eds.), Invasive wild pigs in North America: Ecology, impacts, and management (pp. 369-402). CRC Press.

Naiman, R. J., Pinay, G., Johnston, C. A., \& Pastor, J. (1994). Beaver influences on the longterm biogeochemical characteristics of boreal forest drainage networks. Ecology, 75(4), 905-921. https://doi.org/10. 2307/1939415

National Research Council. (2002). Riparian areas: Functions and strategies for management. National Academies Press.

Okabe, S., Okayama, N., Savichtcheva, O., \& Ito, T. (2007). Quantification of host-specific Bacteroides-Prevotella 16S rRNA genetic markers for assessment of fecal pollution in freshwater. Applied Microbiology and Biotechnology, 74, 890-901. https://doi.org/10.1007/ s00253-006-0714-x
Ralph, J., \& Maxwell, B. D. (1984). Relative effects of human and feral hog disturbance on a wet forest in Hawaii. Biological Conservation, 30, 291-303. https://doi.org/10.1016/0006-3207(84)90048-X

Seward, N., VerCauteren, K., Witmer, G., \& Engeman, R. (2004). Feral swine impacts on agriculture and the environment. Sheep and Goat Research Journal, 19, 34-40.

Singer, F. J., Swank, W. T., \& Clebsch, E. E. C. (1984). Effects of wild pig rooting in a deciduous forest. Journal of Wildlife Management, 48(2), 464-473. https://doi.org/10.2307/3801179

Somarelli, J. A., Makarewicz, J. C., Sia, R., \& Simon, R. (2007). Wildlife identified as major source of Escherichia coli in agriculturally dominated watersheds by BOX A1R-derived genetic fingerprints. Journal of Environmental Management, 82(1), 60-65. https://doi.org/10. 1016/j.jenvman.2005.12.013

Søndergaard, M., Jensen, J. P., \& Jeppesen, E. (2003). Role of sediment and internal loading of phosphorus in shallow lakes. Hydrobiologia, 506-509, 135-145. https://doi.org/10.1023/B:HYDR.0000008611. 12704.dd

Songsteralpin, M. S., \& Klotz, R. L. (1995). A comparison of electron transport system activity in stream and beaver pond sediments. Canadian Journal of Fisheries and Aquatic Sciences, 52, 1318-1326. https://doi.org/10.1139/f95-128

Strauch, A. M., Bruland, G. L., MacKenzie, R. A., \& Giardina, C. P. (2016). Soil and hydrological responses to wild pig (Sus scofa) exclusion from native and strawberry guava (Psidium cattleianum)-invaded tropical montane wet forests. Geoderma, 279, 53-60. https://doi.org/ 10.1016/j.geoderma.2016.05.021

R Core Team. (2019). R: A language and environment for statistical computing. Vienna: R Foundation for Statistical Computing.

Turnipseed, D. P., \& Sauer, V. B. (2010). Discharge measurements at gaging stations. In Stage measurement at gaging stations: U.S. Geological Survey techniques and methods (Book 3; p. 45). USGS. https: //doi.org/10.3133/tm3A8

USEPA. (1999). Standard operating procedure for the analysis of residue, non-filterable (suspended solids) water: Method 160.2. https: //www.nemi.gov/methods/method_summary/5213/

USEPA. (2003). Drinking water advisory: Consumer acceptability advice and health effects analysis on sulfate. https://www.epa.gov/ sites/production/files/2014-09/documents/support_cc1_sulfate_ healtheffects.pdf

USEPA. (2012a). 2012 recreational water quality criteria. https://www.epa.gov/sites/production/files/2015-10/documents/recfactsheet-2012.pdf

USEPA. (2012b). Water: Monitoring \& assessment. https://archive.epa. gov/water/archive/web/html/vms59.html

Wigley, T. B., \& Lancia, R. A. (1998). Wildlife communities. In M. G. Messina \& W. H. Conner (Eds.), Southern forested wetlands (pp. 205-236). Lewis Publishers.

Wood, G. W., \& Roark, D. N. (1980). Food habits of feral hogs in coastal South Carolina. Journal of Wildlife Management, 44(2), 506-511. https://doi.org/10.2307/3807990

How to cite this article: Bolds SA, Lockaby BG, Ditchkoff SS, Smith MD, VerCauteren KC. Impacts of a large invasive mammal on water quality in riparian ecosystems. J. Environ. Qual. 2021;50:441-453. https://doi.org/10.1002/jeq2.20194 